\title{
Nigeria Industrial Policies and Industrial Sector Performance: Analytical Exploration
}

\author{
Udo N. Ekpo \\ Department of Economics, Faculty of Social and Management Sciences, Akwa Ibom State University, Obio \\ Akpa Campus, Akwa Ibom State, Nigeria. \\ udonekpo@yahoo.com
}

\begin{abstract}
In a quest for industrialization in Nigeria, different industrial policies have been implemented. This study explores the industrial policies and the performance of industrial sector. The findings of the study show that the policies, identified as ISI, EPI and FPII, have not helped Nigeria to attain the required level of industrialization that can produce dynamic change in the economic structure of the country and the performance of industrial sector especially manufacturing had been below expectation. The policies have a common feature of foreign inputs reliance which makes their successful implementation in Nigeria very costly. Based on the above, the prospects for Nigeria's industrialization are discussed. Among the recommendations are proper conception and implementation of industrial policy, human capital development especially sciences and technical education for skill development, acquisition of relevant technology in the world, massive public investment in the provision of roads, rail system and electricity, and completion or rehabilitation of industrial core projects especially iron and steel projects.
\end{abstract}

\section{Introduction}

The industrial pattern of Nigeria at political independence in 1960 was that of providing agricultural raw materials needs of the advanced economies, particularly of Britain. The bulk of national income was from exports of primary agricultural products. Available data shows that the share of agriculture in Gross Domestic Product (GDP) was about $63 \%$ and about $80 \%$ of export earnings of the country came from agriculture. The level of industrial activities in the country was very low and, mostly commercial activities owned and run by foreign companies like the United Africa Company (UAC) Ltd., John Holt, Peterson Zonhonis (PZ), Compagnie Francaise de I'Afrique Occidentale (CFAO), Societe' Commerciale de I'Quest Africain (SCOA), and the Union Trading Company (U.T.C). These companies engaged in trade and commerce especially in the importation and distribution of (foreign) manufactured goods. Laying a solid foundation for the development of an industrial economy for Nigeria was not part of the colonial economic policy rather making the colonies perpetual producers of primary raw materials for foreign industries and importers of manufactured goods (Egwaikhide et al, 2001 and Banjoko et al, 2012). Hence, being a major primary products producer and heavy consumer goods importer which underlined the country's external dependence on the uncertain World markets coupled with Western experience to the effect that industrialisation promotes economic growth and development faster than agriculture, industrialization was made the highest priority area for the Nigeria state shortly after political independence (Roberts and Azubuike, 2005).

In attempt to facilitate industrialization in the country, over the years, different industrial policies/industrialization strategies like import substitution approach, export promotion strategy and foreign private investment led industrialization as well as policy reform measures like indigenization policy, structural adjustment programme, etc. have been formulated and implemented. There had been huge public investment in the industrial sector. Government embarked on the establishment of industrial core projects (ICPS) like iron and steel plant at Ajaokuta, steel rolling mills at Warri, Kaduna and Oshogbo, aluminium smeltter plant at Ikot Abasi, crude oil refineries at Port Harcourt and Kaduna, petrochemical and fertilizer factories at Port Harcourt, paper industry at Oku Iboku, cement industries at Calabar and Nkalagu, machine tools company, sugar plants and marble industries. These targeted areas of public sector industrial projects, the so-called industrial core projects (ICPS), were meant to provide the necessary foundation for growth of the industrial sector of the country by providing the basic engineering infrastructure for the production of raw materials, spare parts, equipment components and machinery needed in the various industrial establishments in Nigeria. Furthermore, supporting institutions such as research institutes like Federal Institute for Industrial Research (FIIR) at Oshodi, Project Development Agency (PRODA) at Enugu, Raw Materials Research Development Centre (RMRDC) with offices in almost all the states of the Federation have been established by the government (Adaowo, 2002). To train and produce the needed manpower for the industrial sector, Polytechnics, Conventional universities and universities of technology have been established by the government. 
Despite all the efforts of the government, at least in principle, to kick-start and sustain rapid industrialization in Nigeria, attainment of required level of industrialization that can produce the much needed dynamic change in the economic structure of Nigeria with attendant substantial benefits trickling down to the people has remained an up-hill-task. For over three decades now, economic indicators of level of industrialization in Nigeria are unimpressive. Nigeria's industrial sector has been characterised by high import content of industrial inputs, dwindling capacity utilization, high cost of production, low value added, declining output growth, low employment generation and inadequate linkages with other sectors of the economy (Obioma and Ozughalu, 2005). The annual growth rate of industrial sector as a percentage of GDP is marginal compared to what is obtained in many countries, even countries like Singapore, Malaysia, Indonesia and South Korea which were at the same level of development with Nigeria in the 1960s and the early 1970s (Ekpo, 2005). The contribution of manufacturing to GDP has been declining instead of increasing. The share of manufacturing subsector output in GDP which was $76.6 \%$ in 1975 reduced to $38.3 \%$ in 1985 and $32.4 \%$ in 1998 (CBN, 2002), which by implication portrays Nigeria's industrialization as still at rudimentary level.

The aim of this paper is to explore the various industrial policies so far adopted in Nigeria and the performance of industrial sector. The purpose is to examine the efficacy of the industrial policies, identify their pitfalls as a guide for the future, evaluate their impacts on industrial sector performance as well as discuss prospects for rapid industrialization in Nigeria. In doing so, this paper proceeds as follows: Section 2 presents the conceptual overview. Section 3 overviews the industrial policies. Section 4 focuses upon the performance of the industrial sector while section 5 presents the prospects for better industrial performance. Section 6 concludes the study.

\section{Conceptual Overview}

Industrialization is about the introduction and expansion of industries in a particular place, region or country (Obioma and Ozughalu, 2005). It is a situation where many industries are established in different parts of the country. As many industries are established in a country many different types of products are produced. Industrialization therefore, is a process of building up a country's capacity to produce many varieties of products - extraction of raw materials and manufacturing of semi finished and finished goods. Anyanwu et al (1997) describes industrialization as the process of building up a nation's capacity to convert raw materials and other inputs to finished goods and to manufacture goods for other production or for final consumption. Industrialization enhances the utilization of productive inputs (labour, capital and raw materials), given the country's technology, to produce non-durable and durable consumer goods, intermediate goods and capital goods for domestic consumption, export or further production. Thus industrialization could be described as the process of transforming raw materials, with the aid of human resources and capital goods into (a) consumers goods, (b) new capital goods which allows more consumers goods (including food) to be produced with the same human resources, and (c) social overhead capital, which together with human resources provides new services to both individuals and business (Ekpo, 2005).

Kirkpatrick et al (1985) posited that industrialization involves a number of changes in economic structure of a country such as a rise in the relative importance of manufacturing industry; a change in the composition of industrial output; and changes in production techniques and sources of supply for individual commodities. Industrialization is, indeed, a wide concept. Broadly conceived, it relates to development in many industries/sectors such as manufacturing, banking, building and construction, mining and quarrying, communication, real estate (Obioma and Ozughalu, 2005) and public utilities (Ekpo, 2005). CBN (2002) gives the components of industrial sector in Nigeria to include the manufacturing, construction, electricity, mining, water and gas industries. On the other hand, industrial policy, broadly defined is all forms of state intervention that affect and influence industrial activities (Foreman-Peck and Federico, 1999; Busari, 2005).

\section{Nigeria Industrial Policies /Industrialization Strategies}

Many industrial policies had been adopted since political independence of Nigeria in 1960.The changing nature of Nigeria's industrial policies is classified and discuss as follows:

Import Substitution Industrialization Strategy: Import substitution industrialization (henceforth ISI) was adopted in Nigeria as far as back as 1960 (Ndebbio, 1994) and persisted till 1985 (Bushari, 2005). Often described as an inward looking strategy of industrialisation, ISI refers to domestic production of manufactured goods for domestic markets. It involves processing of raw materials and setting up of manufacturing factories to produce locally certain manufactured goods which were originally imported by a country thereby saving the country from importation of such commodities into the local markets. To get the home industries started and make them survive, it requires the imposition of protective tariffs, import quotas and exchange controls to protect the home industries from foreign competitors by making the entry of foreign goods expensive. ISI was first implemented by Latin American countries following the disruption of import flows by the Second World War and the depression in the international economy between 1927 and 1933 with the aim of reducing imports 
through increased reliance on domestic manufactured goods and to create a favourable balance of payment. Following the perceived success of ISI in these countries, other countries, Nigeria inclusive, adopted it.

The motives of adopting ISI strategy in Nigeria, like that of the Latin American countries, were to reduce the volume of imports and external dependence via increased reliance on goods manufactured domestically, save foreign exchange, create favourable balance of trade and payments, encourage technological development as well as create employment (Egwaikhide, 1997; Bushari, 2005). Furthermore, the local industries, which were largely multinational corporations, were to gradually and over time substitute imported inputs for local inputs. To facilitate the implementation ISI in Nigeria, protectionist measures deemed necessary for its success such as imposition of low tariff rate on imports of intermediate and capital goods, high tariff rates on imports of finished and consumer goods, as well as import licensing, quota and outright prohibition restrictions on imports of certain consumer goods were introduced (Bankole, 2004). A wide range of fiscal, monetary and infrastructural incentives were granted to private sector in the 1960s through 1970s to reduce business cost. These incentives include tax holidays, income tax relief, capital allowance and depreciation allowance for investment in equipment, duty exemption on machinery, spare parts, raw and intermediate materials for manufacturing. Industrial estates were established and let out to industrialists at subsidized rates, thus relieving them of part of the very heavy capital expenditure on getting their business started. To provide the much needed capital to the industrialists, the Nigerian Industrial Development Bank (NDIB) was set up in 1963 by the Federal Government of Nigeria in partnership with the International Finance Corporation to provide loan to Nigerian incorporated companies in the industrial sector (FGN, 1970). In addition, the Federal Loan Board was also established to provide modest financial aid to industrialists.

In pursuit of the ISI objectives, government took steps to pressurize the local and foreign investors, especially importers of manufactured goods to set up local plants. Industries such as textiles, wearing apparels, paints, tyres and tubes, cement and other building materials producing units as well as grain milling factories were established as joint stock ventures with trading companies which originally imported the goods (CBN 2002). With the dramatic increased in the inflow of 'oil funds' in the 1970s, government became a major player in the ISI process by setting up many public enterprises. Heavy industries such as Nitrogenous Fertilizers Projects, Calabar Cement Company, Ngalaku Cement Company, Ikot Ekpene Sunshine Batteries, Nigeria Newsprint Manufacturing Company, Petrochemical Complex, the Kaduna and Warri Refineries, Calabar and Iwopin Pulp and Paper Mills, etc. were established. Government also embarked on large scale capital intensive projects such as Ajaokuta Steel Company Limited, Steel Rolling Company at Aladja, Jos, Kaduna and Oshogbo, and Auto-assembly Plants at Kaduna among others. However, the unfortunate thing about some of these projects was that while some of them were abandoned at construction stage, others were shut down few years into production following the departure of the construction/ maintenance expatriates, none availability of imported raw materials or insufficient funding.

ISI has been described as having four stages (Alokan, 2005). In the first stage, concentration is on the production of basic non-durable consumer goods such as textiles, foodstuffs and pharmaceuticals. The second stage emphasizes specialization in more complex products- consumer durables like cookers, radios, television, motor vehicles etc. Whereas the third stage concentrate in the promotion of intermediates industries in petrochemicals, aluminium and steel as well as production of a wide range of spare parts and component parts for consumer goods industries, the fourth and the final stage involves development of domestic technology through the capital goods industry. Judging from all industrial activities which took place in Nigeria, it may not be out of place to say that all the stages of ISI had been carried out in Nigeria except the final stage, development of domestic technology. We believe that the development of domestic of technology was crucial for the success of ISI strategy in Nigeria as it would have ushered into the country technological breakthrough which is the bedrock of industrialization. None implementation of this crucial aspect of ISI strategy in Nigeria either deliberately or by omission has serious implications. First, it is either those who opted for ISI strategy were ignorance of or not serious about what they were looking for. Secondly, it may be part of international politics of not allowing developing countries, Nigeria inclusive, to have access to technology so as to keep them perpetually dependence on importation of foreign manufactured goods; or how can one explain the crucial stage of ISI strategy being the last stage in it's implementation.

Contrary to the success story of ISI strategy in Latin American countries and the high expectations in Nigeria when it was introduced, it's performance in Nigeria was unsatisfactory. Though manufacturing capacity utilization was high within the period, ISI did not facilitate industrial leap-forward in Nigeria because it focused on the production of consumer goods instead of technological advanced capital goods which sustains industrialization. The original purpose of substituting local inputs for the imported inputs in the local industries was not realised; every input (raw materials, the machines, spare parts and the skilled manpower) used in the local industries were imported. Consequently, instead of reducing imports, external dependence or save foreign exchange as expected, it hiked imports, perpetuated external dependency of industrial sector, and drained foreign exchange. The envisaged transfer of technical skill and technology, which could have resulted in 
technological development in Nigeria and consequently boost industrial development, did not materialized as strategic technical position in existing manufactured firms were manned by foreigners. Ndebbio (1994) posited that ISI in Nigeria failed to lead to desirable level of industrial growth and technological capabilities development as what turned out was mere assemblage of those items rather than manufacturing. Argued further, the brand of ISI adopted in Nigeria seems to differ from the one which produced good result in Latin Americans countries; as it merely involved a relocation of the production centre with little or no change in the other aspects of production function (Adeoye, 2005). The industrial plants were designed abroad only to run on imported raw materials and maintained by foreign experts, thus handicapping efforts aimed at exploring local inputs. The second National Development Plan document (FGN, 1970) recognised the failure in Nigeria's ISI by asserting that instead of expected decline in imports, the implementation of ISI in Nigeria resulted in a rise in the importation of raw materials, intermediate and capital goods.

The manufacturing sector became highly dependent on imported inputs and vulnerable to economic fluctuations of countries where the inputs were imported as well as on foreign exchange earnings of the country. There was serious drain on foreign exchange as manufacturing output was dependent on the ability of the other sectors of the economy, especially export of crude oil, to provide the foreign exchange needed for the importation of the raw materials, machines and spare parts (Adeoye, 2005). With the collapse of international oil market by 1982 and subsequent drastic declined in foreign exchange earnings, Nigerian economy was under serious stress as there was insufficient foreign exchange to pay the high import bills of raw materials, spare parts and components of import-substitution industries. The oil revenue, which provided about $90 \%$ of the foreign exchange earnings, reduced from USS 25.4 billion in 1980 to less than USS 6 billion in 1986 (CBN, 2002). This necessitated rationing of available foreign exchange among manufacturers; leading to acute shortage of essential raw materials, spare parts and components in many industries. Consequently, many industries reduced their capacity utilization and employees drastically, while others were compelled to close down their factories. By the mid 1986, with escalating import bills, mounting external debts obligations and less foreign exchange to settle them following 'oil glut' in the international market, it became obvious that ISI strategy has failed in Nigeria and needs to be discontinued.

Export Promotion Strategy: The urgent need to generate more foreign exchange particularly from non oil sources to meet the country's rising import bills, mounting external debt obligations, rising fiscal responsibilities of the government, and to attend to socio economic responsibilities resulted in the introduction of Structural Adjustment Programme (SAP) in Nigeria in July, 1986, and eventually a shift in Nigeria's industrial policy thrust from ISI approach to export promotion industrialization (henceforth EPI). According to Bamidele (2005) and Banjoko et al (2012), SAP was meant to reverse the downward trends in the economy, widen industrial base, provides stimuli for increased exports and incentives for the manufacturing sector to enlarge its valueadded and contribution to GDP. Export promotion industrialization (EPI) strategy, otherwise described as outward oriented industrialization, involves domestic production of manufactured goods for export. It is government's deliberate efforts to expand the volume of a country's exports through export incentives and other means in order to generate more foreign exchange and improve the current account of the balance of payment (Torado and Smith, 2003; Obioma and Ozughalu, 2005). Pioneered by the newly industrialized countries (NICs) in South East Asia like South Korea, Taiwan, Singapore and Hong-Kong, the success of the NICs process of industrialization, specializing in the production and export of light consumer goods spurred many countries, Nigeria inclusive, to adopt it.

The export oriented industrial policy was meant to achieve a broad objective of accelerating the pace of industrial development in Nigeria. Embedded in this industrial policy package were SAP induced industrial policies like new export promotion decree of 1986, interest rate deregulation policy, the privatization and commercialization policy of 1988, the new export promotion policy/incentives, the new industrial policy of Nigeria of 1989 and debt conversion (equity swap) policy (Nedbbio, 1994). With the new export promotion law, export license requirements for exportation of manufactured goods was abolished, export credit guarantee and insurance schemes was introduced, commodity boards were scrapped to allow the markets forces to be more active and export free zones were established at several locations in the country (Essia and Ibor, 2005). The hitherto regulated interest rate in the country was deregulated to stimulate foreign capital inflow, encourage Nigerians to repatriate capital flight, induce saving and restrain credit expansion. The discount rate was raised from $11 \%$ to $14 \%$ in 1987 with minimum lending rate fixed at $14 \%$. The new export policy/incentives permitted Nigerian exporters of non-oil (industrial) products to retain for use $100 \%$ of their export proceeds in foreign currency instead of $25 \%$ permitted before the introduction of new export policy. Privatization and commercialization policy, which was aimed at reducing the dominance of unproductive investment in the public sector, down-sizing public sector and increase private sector participation in the economy, led to the setting up of Technical Committee on Privatization and Commercialization (TCPC). Many public enterprises like Flour Mills of Nigeria Limited, African Petroleum Limited, National Oil and Chemical Company, Aba Textile Mills, United Nigerian Insurance Company, Northern Breweries among others were privatized. However, one of the 
observable facts about the privatized public enterprises is that because of the impropriety associated with it, some of them are yet to resume full production after many years of privatization.

The goals of New Industrial Policy of 1987 (believed to be a replacement of the amended Indigenization Policy of 1977) were to increase exports of manufactured goods, improve the technological skills and capability available in the country, increase local content of industrial output, improve incentives for attracting foreign capital and increase private sector participation in the manufacturing sector (Ndebbio, 1994). In this policy, government accorded high priority to promotion of small and medium scale enterprises. The policy focused on the regulatory environment, promotion of export free zone, liberation of access to foreign exchange and continued promotion of market determined exchange rate for the Naira. An important feature of new industrial policy of 1989 was reduction of Nigerian's control and ownership structure of enterprises as foreigners were permitted to compete with Nigerian in all other businesses except those of banking, insurance, petroleum prospecting and mining. The Debt Equity Swap policy was implemented to reduce Nigeria's external debt and debt servicing obligation, attract foreign investment and technology, and diversify the country's export base.

By all indications export promotion has not make much impact in Nigeria's industrial sector and seems not to yield the expected benefits. Agreeing with this assertion, Uniamikogbo (1996) noted that EPI strategy in Nigeria which emphasized the promotion of value-added non-oil exports especially manufactures has not actually achieved significant result. Ekpo (2005) also noted that the impact of SAP and attendant EOI approach to industrialization produced mixed results in Nigeria. While it reduced the size of public sector's investment in the economy, increased private sector participation in the industrial sector and provided more access to foreign market, the adverse effects of devaluation, high interest rate and tight monetary policy which prevailed during the period increased the cost of production and reduced the profit margin of the firms. Small and Medium Enterprises (SME) were the most badly affected since they could not compete favourably with importers and large scale industrialists in the foreign exchange market.

Moreover, like the ISI strategy which was discarded, the EPI approach also depended largely on the foreign technologies and inputs. The raw materials, machines, spare parts and other inputs needed for EPI were imported from abroad at very exorbitant rates. This hiked production cost, resulting in high prices and non competitiveness of Nigerian goods in the world markets. Essien (2005) asserted that the mode of EPI in Nigeria caused the prices of Nigerian goods to be dearer, both locally and internationally, than their foreign counterparts and consequently, Nigerian products are accorded very low demand.

In addition, the success of Nigeria's EPI had been strongly hampered by deliberate attempts by industrialized countries to keep unindustrialized countries perpetually unindustrialized through imposition of high tariff and quotas that does not favour less developed countries manufacturing exports, including manufacturing exports from Nigeria. Hellenier (1972) acknowledged this fact and asserted that of fundamental importance to the Third World manufacturing export prospects are the barriers which are erected by the developed countries to restrict the entry of these products to their own markets. Tariffs, quotas and other barriers in the markets of the industrialized countries constitute major impediment to large-scale export of the LDCs. The tariff structures of the rich nations are such that offer the greatest degree of effective protection to their producers in the very industries in which poor countries are most likely to be competitive - light industries relatively intensive in the use of unskilled labour such as textiles, footwear, handbags, rugs, sporting goods, processed foodstuffs, etc. This is precisely because of these industries inability to compete freely, unskilled labour intensity putting them at a comparative disadvantage within the context of their relatively high wage economies.

Foreign Private Investment Led Industralization Strategy: Several years of military dictatorship rule in Nigeria (1966-1979, 1983-1999 exclusion of the Interim Civilian Administration of August-November, 1993) make the country unattractive to foreign investors, hence Nigerian economy was shut-off from meaningful foreign investment. On assumption of power in 1999 by the civilian administration there was urgent need to reverse the trend, restore investor's confidence on Nigerian economy and convert Nigeria from the parish status it has assumed to an investor's friendly nation. Moreover, there was need to attract massive inflow of foreign capital because the high level of corruption and mismanagement prevalence in the country strongly constrained mobilization and utilization of domestic resources for expected level of industrial development (Busari, 2005). This marked the en-route of Foreign Private Investment led industrialization (henceforth FPII) into Nigeria's industrial policy parlance as another industrialization strategy. Foreign private investment is a direct investment into production or business in a country by an individual or company in another country, either by buying a company in the target country or by expanding operations of an existing business in that country. While in a narrow sense it involves building new facilities, broadly speaking it includes building new facilities, mergers and acquisitions, reinvesting profits earned from overseas operations and intra company loan (Wikipedia, 2013). In pursuing FPII objectives, efforts had been made to handle the twin monsters, the problems of decaying infrastructures and corruption, which scarred away many potential foreign investors from Nigeria. Attempts had 
also been made to break the bureaucratic bottlenecks which inhibited registration and establishment of foreign businesses in Nigeria through the abolition of Land Use Act and the Nigerian Enterprise Promotion Decree. The One-Stop investment centre had been established by the Nigerian Investment Promotion Commission to hasten the processing of application for entry into Nigeria by prospective foreign investors, and registration and establishment of businesses. To sanitize and stabilize the financial system, banking sector reforms including the universal banking of 2002 and the banking consolidation exercise of 2005 were carried out. Other measures adopted include evolvement and implementation of the strategic management of industrial development through an industrial master plan since 1999. As provided for in the plan, state owned enterprises had been reviewed with the aim of completing or rehabilitating viable ones and eventually privatising them. In the master plan there is provision to strengthen industrial research and commercialize research findings as well as sourcing for technical assistance for industrialists in the area of technology transfer and capacity building. In addition, the Small and Medium Enterprises Development Agency of Nigeria (SMEDAN), an umbrella agency for small and medium enterprises (SMES) had been established to cater for the development of SMES.

On the benefit of this strategy, obviously, the rate of net inflow of foreign private investment into the country has increased. However, the insecurity threat in the country posed by Boko Aram insurgence, political violence, ethnic militia and wide spread flood if not properly handle may hamper further inflow of foreign private investment and jeopardise the success of FPII in Nigeria. The performance of manufacturing sector is weak as indicated by dwindling level of capacity utilization. The profit margin of firms is low due to high cost of production caused by shortage of critical infrastructure like electricity, transportation, etc. and the fact that machinery, spare parts, raw materials and technology are imported.

\section{Nigeria's Industrial Sector Performance}

The motives of industrial policies was to address the macro problem of economic growth, unemployment, balance of payment deficit by reducing imports and raising manufacturing exports, technology transfer and technical progress. The performance of industrial sector in relation to industrial policies objectives is examined using industrial performance indicies such as index of industrial and manufactured production, percentage contribution and value added to the Gross Domestic Product, manufacturing capacity utilization, percentage growth rate, manufacturing share in total export, import and employment. The examination of industrial sector performance involves its' sectoral components. The components of industrial sector are manufacturing, mining, electricity, construction, water and gas (Kirkpatrick et al, 1984). In this work, we concentrate on manufacturing, mining and electricity. However, more attention is accorded manufacturing since the degree of manufacturing in the country measures the extent to which other components have been effectively utilized (Ndebbio, 1994).

Industrial Production: The output of industrial sector is measured by the index of industrial production. Tables 1 presents index of industrial production between 1970 and 2005 with 1985 as the base year. The production growth rates have been generally low and sometimes negative particularly since the 1980s following the global economic crises which seriously affected Nigeria foreign exchange earnings from the sale of crude oil. As shown in Table 1, industrial production had been so erratic. It rose from an index of 41.3 in 1970 to 119.9 in 1980 and climaxed at 122.9 in1982. It declined to 91.6 in 1984. From 1986 to 2003, industrial production fluctuates between an index of 103.5 and 146.7 and stood at 158.8 in 2005. The output of manufacturing industry measured by the index of manufacturing production which was 24.1 in 1970 increased to 128.6 in 1982. There was a decline in manufacturing output from 1983 to 1986 . The index of manufacturing was only 78.2 in 1986. This decline was as a result of the downturn in the Nigerian economy, caused by the fall in world prices of crude oil, which culminated to the adoption of Structural Adjustment Programme (SAP) in July, 1986. The various SAP induced industrial policies and incentives adopted helped to boost manufacturing production for a short while. The index of manufacturing production rose to 130.8 in 1987 and reached it's peak of 178.1 in 1991. Because there was no in-built mechanism to sustain the growth, there was fluctuating decline to 145.2 and 133.1 in 1993 and 1998 respectively. Between 1999 and 2003, there was a marginal increase in manufacturing production. The index of manufacturing production stood at 137.1 in 1999 and 147.9 in 2003. It declined abruptly to about 89 in 2004 and 2005.

Table1: Index of Industrial Production, 1970-2008 (1985=100) and Capacity Utilization

\begin{tabular}{|l|l|l|l|l|l|l|}
\hline \multirow{2}{*}{ Year } & \multicolumn{3}{|c|}{ Index of Industrial Production } & \multicolumn{2}{c|}{ Manu. Capacity Utilization (\%) } \\
\cline { 2 - 8 } & Manufacturing & Mining & Electricity & $\begin{array}{l}\text { Total (All } \\
\text { Sector) }\end{array}$ & $\begin{array}{l}\text { Capacity } \\
\text { Utilization }\end{array}$ & $\begin{array}{l}\text { Growth Rate } \\
(\%)\end{array}$ \\
\hline 1970 & 24.1 & 72.2 & 18.2 & 41.3 & 80.2 & - \\
\hline 1975 & 43.9 & 119.9 & 42.2 & 71.0 & 76.6 & - \\
\hline 1980 & 102.4 & 138.5 & 74.8 & 119.0 & 70.1 & - \\
\hline 1981 & 117.3 & 96.2 & 89.4 & 115.6 & 73.3 & -13.23 \\
\hline 1982 & 128.6 & 86.2 & 94.9 & 122.9 & 63.6 & -2.8 \\
\hline 1983 & 94.8 & 82.5 & 97.1 & 96.4 & 49.1 & \\
\hline
\end{tabular}


Nigeria Industrial Policies and Industrial Sector Performance: Analytical Exploration

\begin{tabular}{|c|c|c|c|c|c|c|}
\hline 1984 & 83.4 & 93.0 & 87.1 & 91.6 & 42.0 & -14.46 \\
\hline 1985 & 100.0 & 100.0 & 100.0 & 100.0 & 37.1 & -11.67 \\
\hline 1987 & 130.8 & 88.4 & 118.8 & 122.1 & 40.4 & 3.86 \\
\hline 1989 & 154.3 & 109.2 & 105.2 & 125.0 & 42.5 & 2.41 \\
\hline 1990 & 162.9 & 115.1 & 124.8 & 130.6 & 39.0 & -8.24 \\
\hline 1991 & 178.1 & 120.1 & 125.3 & 138.8 & 39.4 & 1.03 \\
\hline 1993 & 145.5 & 124.6 & 142.2 & 131.7 & 36.2 & -10.40 \\
\hline 1994 & 144.2 & 121.1 & 152.7 & 129.2 & 30.4 & -16.02 \\
\hline 1995 & 136.3 & 124.4 & 150.2 & 128.8 & 29.3 & -3.62 \\
\hline 1996 & 138.7 & 129.0 & 147.1 & 132.5 & 34.7 & 18.43 \\
\hline 1997 & 138.7 & 130.6 & 142.9 & 140.6 & 34.2 & -1.45 \\
\hline 1998 & 133.1 & 134.1 & 134.4 & 133.9 & 32.4 & -5.26 \\
\hline 2002 & 146.3 & 133.7 & 146.6 & 143.2 & 44.3 & 3.75 \\
\hline 2003 & 147.9 & 146.6 & 147.2 & 146.7 & 56.9 & 28.44 \\
\hline 2004 & 145.7 & 154.0 & 148.0 & 151.2 & 55.7 & -2.11 \\
\hline 2005 & 145.8 & 154.0 & 291.0 & 158.8 & 54.80 & -1.62 \\
\hline
\end{tabular}

Source: CBN Annual Report and Statement of Account (Various Issues).

Table 2 shows the average growth rate of manufacturing production. It rose to $13.6 \%$ between 1976 and 1980 and fell drastically to $-3.6 \%$ between 1981 and 1986. It rose again to $14.65 \%$ between 1987 and 1990 , and declined to $-1.94 \%$ between 1995 and 1998. The growth rate in manufacturing production experienced up to early $1980 \mathrm{~s}$ is attributed to increased revenue from crude oil export which made available enough foreign exchange for importation of manufacturing raw materials, spare parts and machineries. With the oil glut in the mid 1980s, Nigeria's foreign exchange earning was very low and cannot pay for imported manufactured raw materials, spare parts and machineries. Consequently, manufacturing production in the country fell drastically. Though it improved with the introduction of SAP but it was short-lived and since then, it has been epilectic.

Table 2: Average growth Rate of Industrial Production in Nigeria (\%)

\begin{tabular}{|l|l|l|l|}
\hline Year & $\begin{array}{l}\text { Av. Growth Rate of Manufacturing } \\
\text { Production }\end{array}$ & $\begin{array}{l}\text { Av. Growth of Mining } \\
\text { Production }\end{array}$ & $\begin{array}{l}\text { Av. Growth Rate of Electricity } \\
\text { Production }\end{array}$ \\
\hline $1970-1975$ & 10.5 & 8.8 & 15.1 \\
\hline $1976-1980$ & 13.6 & -0.1 & 8.1 \\
\hline $1981-1986$ & -3.6 & 0.3 & 5.1 \\
\hline $1987-1990$ & 14.65 & 4.55 & 5.6 \\
\hline $1991-1994$ & -2.64 & 1.32 & 5.2 \\
\hline $1995-1998$ & -1.94 & 2.72 & -12.4 \\
\hline $1999-2002$ & 4.13 & -1.24 & 7.8 \\
\hline
\end{tabular}

Source: Computed from CBN Annual Report and Statement of Accounts, Various Issues.

Table 3 presents the average annual growth rate of the industrial sector and the manufacturing subsector as a per cent of GDP of Nigeria and that of some other countries. This table is quite revealing. It shows that between 1990 and 2002, the industrial sector/GDP ratio and manufacturing/GDP growth rate of Nigeria were very low compared to that of countries like Botswana, Singapore and Malaysia which were at the same level development with Nigeria in the 1970s. While the industrial sector/GDP growth rates of Nigeria were $-1.0 \%$ and $0.9 \%$ between 1980 and 1990 and between 1990 and 2002 respectively, manufacturing/GDP ratio stood at $0.7 \%$ and $1.2 \%$ between 1980 and 1990 and between 1990 and 2002 respectively.

Table3: Comparing Average Annual Growth of Industry as Per cent of GDP (1980-2002)

\begin{tabular}{|l|ccc|rc|}
\hline & Industry & & \multicolumn{2}{c|}{ Manufacturing } \\
\hline Countries & $1980-90$ & $1990-95$ & $1990-2002$ & $1980-90$ & $1990-2002$ \\
\hline Nigeria & -1.0 & -1.2 & 0.9 & 0.7 & 1.2 \\
Botswana & 11.4 & 1.4 & 4.3 & 11.4 & 4.0 \\
Singapore & 5.4 & 9.2 & 7.3 & 6.6 & 6.9 \\
Malaysia & 7.2 & 11.0 & 7.5 & 9.3 & 8.8 \\
Sub-Saharan Africa & 0.6 & 0.2 & 1.9 & 1.7 & 1.9 \\
\hline
\end{tabular}

Source : Ekpo (2005)

Manufacturing Capacity Utilization: Manufacturing capacity utilization presented in Table 1 is another important indicator of industrial sector's performance. The table shows that manufacturing capacity utilization 
in Nigeria has declined greatly, and especially from 1983 it has been very low. The manufacturing capacity utilization which was $80.2 \%$ in 1970 declined to $66.8 \%$ in 1979. It rose to $73.3 \%$ in 1981 after which fell drastically to $37.1 \%$ in 1985. With the introduction of SAP in 1986, there was marginal increase between 1986 and 1989. At 1989, it stood at 42.5\%. It declined to $29.3 \%$ in 1995. Between 1996 and 2003 there was slight increase. In 2002, the average capacity utilization was $44.3 \%$. It rose to $56.5 \%$ in 2003 but declined slightly to about $55 \%$ in 2005.

Value Added to GDP: Table 4 presents the share of the industrial sub-sector to GDP in Nigeria. The table reveals that the industrial sector of the Nigerian economy is small in size and structurally weak. The contribution of different components of industrial sector is generally low. The contribution of manufacturing sub sector to gross domestic product is insignificant. In 1960 and 1965, the percentage share of manufacturing in GDP was about $4.8 \%$ and $6.9 \%$. It rose to $9 \%$ in 1970 , about $10 \%$ in 1980 , and $11.2 \%$ in 1982 but declined to 7.8\% in 1984. Between 1985 and 1991 it stagnated at about $8.0 \%$, declined to $3.91 \%$ in 2005. Low share of manufacturing in total GDP is associated with low value added. It follows that if the share of manufacturing in total GDP of an economy is low, then the value added will be very low.

Share of Manufacturing in total Export, Import and Employment: As shown in Table 5, the share of manufacturing production in total exports for periods 1980-1990, 1990-1995, and 1995-2001 were not up to $1.0 \%$. They were $0.48 \%, 0.17 \%$ and $0.26 \%$ respectively. In average, the period $1980-2001$ showed only a $0.39 \%$ contribution of manufactured goods to total export. The share of manufacturing in import was as high as $82.9 \%$ for period 1980-2001. The manufacturing employment, in average, was 167,270 persons for the period 19802001. This is quite low, especially in a country where youth unemployment is very high.

Growth of Manufacturing Subsector's Output: Table 6 shows growth of manufacturing output across it's three major subsectors- consumer goods, intermediate goods and capital goods subsectors. The consumer goods subsector (comprising sugar, soft drink, beer and stout, cotton, synthetic fibre, footwear and soap detergents) recorded a positive growth of 3\%, $0.2 \%$ and $0.81 \%$ during the periods 1970-85, 1995-2001 and 1970-2001 respectively.

Table 4: Share of Industrial Subsectors to GDP in Nigeria, 1980-2007 ( \%)

\begin{tabular}{|c|c|c|c|c|c|}
\hline Year & Manufacturing & Crude Petroleum & $\begin{array}{l}\text { Mining \& } \\
\text { Quarrying } \\
\end{array}$ & Electricity & $\begin{array}{l}\text { Building \& } \\
\text { Construction }\end{array}$ \\
\hline 1981 & 9.8 & 14.1 & 1.2 & 3.58 & 4.1 \\
\hline 1982 & 11.2 & 12.5 & 1.3 & 4.03 & 3.8 \\
\hline 1983 & 8.4 & 12.7 & 1.0 & 4.15 & 3.5 \\
\hline 1984 & 7.8 & 15.2 & 0.9 & 4.45 & 3.0 \\
\hline 1985 & 8.6 & 15.1 & 0.5 & 4.51 & 1.9 \\
\hline 1986 & 7.9 & 13.8 & 0.3 & 2.89 & 1.8 \\
\hline 1987 & 8.4 & 12.3 & 0.3 & 3.05 & 2.0 \\
\hline 1988 & 8.6 & 12.3 & 0.3 & 2.86 & 2.0 \\
\hline 1989 & 8.2 & 13.3 & 0.3 & 2.88 & 1.9 \\
\hline 1990 & 8.2 & 12.9 & 0.2 & 1.95 & 1.9 \\
\hline 1991 & 8.5 & 13.4 & 0.3 & 2.82 & 1.9 \\
\hline 1992 & 8.4 & 13.5 & 0.3 & 3.07 & 1.9 \\
\hline 1993 & 7.34 & 13.08 & 0.29 & 3.07 & 1.96 \\
\hline 1994 & 7.18 & 12.5 & 0.31 & 3.27 & 1.99 \\
\hline 1995 & 6.65 & 12.62 & 0.30 & 3.15 & 2.00 \\
\hline 1996 & 6.48 & 13.05 & 0.30 & 3.09 & 1.96 \\
\hline 1997 & 6.29 & 13.63 & 0.30 & 2.98 & 1.92 \\
\hline 1998 & 5.9 & 12.0 & 0.32 & 2.71 & 2.10 \\
\hline 1999 & 4.72 & 32.09 & 0.13 & 2.72 & 0.86 \\
\hline 2000 & 3.70 & 48.19 & 0.10 & 2.64 & 0.67 \\
\hline 2001 & 3.89 & 42.94 & 0.12 & 2.87 & 0.79 \\
\hline 2002 & 4.59 & 38.31 & 0.11 & 3.52 & 0.72 \\
\hline 2003 & 4.08 & 38.31 & 0.08 & 3.33 & 0.62 \\
\hline 2004 & 3.68 & 43.33 & 0.26 & 3.46 & 1.44 \\
\hline 2005 & 3.79 & 25.72 & 0.27 & 3.46 & 1.52 \\
\hline 2006 & 3.91 & 24.26 & 0.28 & 3.41 & 1.62 \\
\hline
\end{tabular}

Source: Computed from CBN Annual Report and Statement of Accounts, Various Issues.

Table 5. Share of Manufacturing in total Export, Import and Employment (Average \%)

\begin{tabular}{|l|l|l|l|l|}
\hline Indicators & $1980-90$ & $1990-95$ & $1995-2001$ & $1980-2001$ \\
\hline Shares in total exports (\%) & 0.48 & 0.17 & 0.26 & 0.39 \\
\hline Share in total import (\%) & 81.1 & 87.3 & 80.4 & 82.9 \\
\hline
\end{tabular}


Nigeria Industrial Policies and Industrial Sector Performance: Analytical Exploration

\begin{tabular}{|l|l|l|l|l|}
\hline Value of Manu. Export (Nm) & 773.8 & 310.1 & 291.96 & 557.3 \\
\hline Manu. Employment (1000) & 274.49 & 45.86 & 40.08 & 167.27 \\
\hline
\end{tabular}

Source: CBN Annual Report and Statement of Accounts (Various Issues)

Table 6. Growth in Manufacturing Subsector's Output (Average \%)

\begin{tabular}{|l|c|c|c|c|}
\hline Subsector & $1970-85$ & $1986-2001$ & $1995-2001$ & $1970-2001$ \\
\hline Consumer Goods & 3.0 & -0.2 & 0.2 & 0.81 \\
\hline IntermediateGoods & 2.9 & -0.5 & -0.4 & 0.91 \\
\hline Capital Goods & 7.2 & -4.6 & -1.5 & -2.3 \\
\hline
\end{tabular}

Source: Adenikinju (2002)

Between 1986 and 2001, the consumer goods subsector had a negative growth of $0.2 \%$. The intermediate goods subsector (consisting of Paints, Refined products, Cement and Roofing sheets) had a positive growth of $2.90 \%$ and $0.91 \%$ in the periods $1970-85$ and 1970-2001 respectively. For periods 1986-2001 and 1995-2001, the intermediate goods subsector recorded negative growth of $0.5 \%$ and $0.4 \%$ respectively. Except for the period 1970-85 which the capital goods subsector (comprising Vehicle assembly, Radio and Television) recorded a positive growth of 7.20\%, for other periods 1986-2001,1995-2001 and 1970-2001 there were negative growth of $4.6 \%, 1.5 \%$ and $2.3 \%$ respectively. A cursory look at the table reveals that the growth rate of all the manufacturing subsectors were better in the period 1970-85 than in other periods. This is attributed to capital goods accumulation makes possible by huge inflow foreign exchange earnings from crude oil exportation.

\section{Prospects for Better Industrial Performance in Nigeria}

Nigeria's inability to actualize its industrialization aspiration is often blamed on the strategies adopted so far as been faulty. Such hasty conclusion could be very misleading. Though Nigeria's industrialization strategies are not completely absolved of blame, Nigeria industrial development has been constrained by a myriad of factors. Among them include the following:

Poor Conception and Implementation of Industrialization Strategies: Industrialization programmes/strategies so far adopted in Nigeria failed to bring about expected results because they were poorly conceived and haphazardly implemented. As Roberts and Azubuike (2005) had observed, Nigeria's industrial policy and strategy was not necessarily a unitary, closely coordinated or planned programme of the state intervention; rather it consisted of an improvised amalgam of ad hoc objectives and instruments intended to influence the behaviour of firms and other stakeholders. Besides, the industrial programmes were not well implemented. As (Ekpo, 2005) has noted, if the industrial programmes/policies of previous years (1960-1965, 1970-1974, 1975-1980, and 1985-1988 development plans) and various sectoral policies were properly implemented, Nigeria would have been on the path of sustained growth and development a long time ago and policy makers would have been occupied with fine tuning and adapting to new realities given the dynamic of the world. The implementation of industrial programmes in Nigeria has generally been casual. It was not given the kind of serious attention it deserves. Government provided tax incentives and subsidies to induce foreign owners/controllers of industrial capital and technologies to transfer their factors for activities in Nigeria but there was little or no set up mechanism to monitor or supervise the operation of the induced foreign and indigenous enterprises to ensure compliance with the industrial policy objectives of the country. We are of opinion that there is no way such a care-free attitude would have succeeded in achieving significant positive results for the domestic economy in the self-seeking, competitive and contemporary world.

Technological Development: Though technological capability is a crucial factor for industrial development, the pursuit of development of local technological capability was not given serious attention in Nigeria early enough not until after the Third National Development Plan. It was after 1975 that government started to realize the need to consciously pursue the development of technological capability. However, we believe that in pursuing this critical ingredient of industrialization, the government should have been more vigorous and aggressive in the way and manner it was going about it. Agreed, many Technical Colleges, Polytechnics and Universities of Technology have been established; and students have been encouraged to undertake science-and-technology related subjects/courses. It is surprising to note that standard science laboratory/practical workshop are lacking in some of these institutions. In most cases, practical materials for laboratory experiments and workshop practical where students could acquire non-proprietary technology are not provided. Non-proprietary technology is essential for local technological capability development and could be acquired through learning and imitation in technically oriented institutions. For acquisition of this important aspect of technology, we believe that the practical workshop in institutions of learning should have sufficient stock of component parts of simple 
machines and electronic appliances. Students in technical colleges and polytechnics should be well familiar with those component parts as well as know how to fixed simple machines. In the University, students should know the mechanism of those components parts/machines and how to improve on them to perform better.

The other aspect of technology, proprietary technology, which involves specialized knowledge acquired as a result of many years of private research effort is usually guarded jealously by it's possessor. It can only be acquired by none possessor either directly through negotiation or indirectly through an agent. We are of opinion that government should make conscious and deliberate efforts to identify, negotiate for and acquire available technology in the world in specific areas. Such acquisition should be a national issue and not a local firm's affair. Government should involve in all technology transactions between local firms and foreign proprietors of technology to strengthen the bargaining position of local firms in technology transactions so that they can get favourable terms from their trading partners or at least eliminate restrictive ones.

Inadequate Infrastructure: The quantity and quality of infrastructure facilities available affect the production cost and manufacturing output and consequently, the profitability of business firm. The production cost and output level thus affected, in turn affect the competitiveness of domestic products in both domestic and international markets. Efficient and adequate provision of infrastructure such as transportation, water supply, electricity supply and telecommunications are enablers which are crucial for industrialization. Following long period of neglect, most infrastructure facilities in Nigeria are in deplorable state. Most of the roads are in different stages of disrepair while the rail system has collapsed. Added to this is the inadequate and erratic power supply in the country which is inimical to industrial developments. The unreliable and inadequate infrastructure in Nigeria greatly deterred industrial development because of many economic costs such as direct cost of production and production delay associated with it. These costs lead to high cost of production and under utilization of existing production capacity. Inadequate and inefficient infrastructure services has also raised capital costs of manufacturing firms since in most cases, it requires the users to invest in alternative source. Hence, there should be massive investment in the provision of infrastructure in the country.

Non-Completion and Functioning of Industrial Core Projects (ICPs): As earlier stated, industrial core projects such as steel plants, the paper plants, the fertilizer plants, the petrochemical plants, liquefied natural gas (LNG) project, the Nigerian machine tools company, etc embarked upon by the government are the bedrock for Nigeria industrialization. They were meant to provide industrial raw materials, spare part, components, etc which will help industrial sector to be self sustaining and ensure long run growth. None completion/or proper functioning of these outfits constitute one of the greatest obstacle to Nigeria's industrial development. Unless these industrial core projects, especially the steel plants, are completed or rehabilitated and make to function effectively, there will be continuous importation of necessary machinery, spare parts and industrial raw materials from abroad at high cost which is inimical to Nigeria's industrial development.

\section{Conclusion and Recommendations}

This paper analytically explored the industrial policies implemented in Nigeria and industrial sector's performance. The industrial policies so far implemented in Nigeria are identified to include ISI, EPI and FPII. A common feature of these policies had been foreign inputs (capital, technology and even skilled labour) reliance; which by implication Nigeria had been pursuing dependent industrialization. Industrial policies adopted were poorly conceived and casually implemented. Though the government have made reasonable effort, the prerequisites for industrialization are not completely present or have not been met in Nigeria. In addition, certain salient ingredients needed for industrial development have not been given deserves attention in Nigeria. Thus far, these policies have not helped to actualise Nigeria's industrialization aspiration. First, there had been high cost of production resulting in non-competitiveness of Nigeria's manufactured goods in both domestic and foreign markets. Secondly, manufacturing production had concentrated on light consumer goods instead of capital goods which sustain industrialization. Thirdly, the performance of industrial sector especially manufacturing, by all indications, had been far below expectation.

For industrial sector to develop and perform better, this study proposes a "Home Grow Industrial Policy" where ISI and EPI are jointly pursued and industrial inputs domestically sourced. The EPI should be on specific items which Nigeria has comparative advantage. Industrial policy should be properly conceived and carefully implemented. Human capital development should be given priority in the country, with education especially sciences and technical education properly funded for skill development. To sustain industrialization in Nigeria, manufacturing production should begin to focus on the production of capital goods. Government should make conscious and deliberate efforts to negotiate and acquire available technology in the world in specific areas. The acquisition of technology should be a national issue and not a local firm affair. There should be massive public investment in the provision of electricity, roads, rail system and other infrastructure. National security should be strengthened and tightened to curb the activities of Boko Haram, armed robbers, kidnappers 
and ethnic militants so as to protect and encourage investment in the country. The industrial core projects (ICPs), especially Ajaokuta Iron and Steel Plants, embarked upon by the government should be completed or rehabilitated and make to function properly in the country.

\section{REFERENCES}

[1]. Adaowo, M. A. (2002). The need for Technological Development in Nigeria. Jos Journal of Economics, 2(1), December, pp.917.

[2]. Adenikinju, A. (2002). Africa imperative in the new world trade order; country case study of the manufacturing sector : Nigeria. Report presented to AERC, Nairobi, Kenya.

[3]. Adeoye, B. W. (2005). Industrial Development in Nigeria in the Context of Globalization. In: The Challenge of Industrialization: A Pathway to Nigeria Becoming a Highly Industrialized Country in the Year 2015, Nigerian Economic Society, Ibadan, pp.275-303.

[4]. Alokan, O. O. (2005). Theoretical Perspectives on Nigeria's Industrialization. In: The Challenges of Industrialization: A Pathway to Nigeria becoming a Highly Industrialized Country in the year 2015, Nigerian Economic Society, Ibadan, pp.29-62.

[5]. Anyanwu, J. C., Oyefusi, A., Oaihenan, H. and Dimowo, F. A. (1997). The Structure of the Nigerian Economy. Onitsha, Nigeria: Joanee Educational Publishers Ltd

[6]. Bamidele, R. O. (2005). "Globalization and the Nigerian Manufacturing Sector'. The Nigerian Journal of Economic and Social studies, Vol. 47(2), pp.281-332.

[7]. Banjoko,S. A., Iwuji, I. I., Bagshaw, K. (2012). "The Performance of the Nigerian Manufacturing Sector: A 52-Year Analysis of Growth and Retrogression (1960-2012)', Journal of Asian Business Strategy, 2(8), pp. 177-191.

[8]. Bankole, A. S. (2005). Nigreia's Industrialization Strategy under Multilateral Trade Agreements. In: The Challenges of Industrialization: A Pathway to Nigeria becoming a Highly Industrialized Country in the Year 2015. Nigerian Economic Society, Ibadan, pp.147-178.

[9]. Busari, D. T. (2005). Foreign Capital, Globalization and the Challenges of Industrialization in Nigeria. In: The Challenges of Industrialization : A Pathway to Nigeria becoming a Highly Industrialized Country in the Year 2015. Nigerian Economic Society, Ibadan, pp. 521-551.

[10]. CBN (2002). The Changing Structure of the Nigerian Economy and implication for Development. Lagos: Realm Communication Ltd.

[11]. Egwaikhide, F. O. (1997). Import Substitution Industrialization in Nigeria: A Selected Review. Nigerian Journal of Economic and Social Studies, 39(2), pp.183-203

[12]. Egwakhide, F. O., Ekpo, A. H., Oyeranti, O. and Ayodele, O. (2001). Four Decades of Industrialization in Nigeria : A Critical Analysis. Nigeria Journal of Economics and Social Studies, 42(2), pp.365-391.

[13]. Ekpo, A. H. (2005). Industrialization and Nigeria's Economic Development. In : The Challenges of Industrialization : A Pathway of Nigeria Becoming a Highly Industrialized Country in the Year 2015, Nigerian Economic Society, Ibadan, pp.3-26.

[14]. Essien, E. B. (2005). Developing and Sustaining Indigenous Technology for Sustainable Industrialization in Nigeria. In: The Challenges of Industrialization: A Pathway to Nigeria becoming a Highly Industrial Country in the Year 2015, Nigerian Economic Society, Ibadan, pp.463- 490.

[15]. Essia, U. and Ibor, U. E. (2005). Industrialization and Import Addition in Nigeria - a Keynesian - Structuralist Perspective. In: The Challenge of Industrialization: A Pathway to Nigeria Becoming a Highly Industrialised Country in the Year 2015, Nigerian Economic Society, Ibadan, pp.99 - 116.

[16]. Foreman-Peck, J. and Fedrico, G. (1999). European Industrial Policy: The Twentieth Century Experience, Oxford: Oxford University Press.

[17]. FGN (1970). Second National Development Plan, 1970 - 75, Lagos, Central Planning Office.

[18]. Hellenier, G. K. (1972). International Trade and Economic Development, England, Harmondsworth.

[19]. Kirkpatrick, C. H., Lee, N. and Nixson, F. I. (1984). Industrial Structure and Policy in Less Developed Countries. Hemel Hempstead, United Kingdom, George Allen \& Unwin (Publishers) Ltd.

[20]. Ndebbio, J. U. (1994). Industrial Development Policies/Incentives and Their Impact on the Nigerian Economy. In: Ndebbio and Ekpo (eds.). The Nigerian Economy at Crossroads: Policies and Their Effectiveness. Calabar, University of Calabar Press, pp.1113.

[21]. Obioma, E. C. and Ozugahalu, U. M. (2005). Industrialization and Economic Development: A Review of Major Conceptual and Theoritical Issues. In: The Challenges of Industrialization : A Pathway to Nigeria becoming a Highly Industrialized Country in the Year 2015, Nigerian Economic Society, Ibandan , pp.63-97.

[22]. Robert, E. O. N. and Azubuike, U. C. (2005). The State, Politics and Deindustrialization in Nigeria. In : The Challenges of Industrialization : A Pathway to Nigeria becoming a Highly Industrialized Country in the Year 2015, Nigerian Economic Society, Ibadan, pp. 307-336.

[23]. Torado, M. P. and Smith, S. C. (2003). Economic Development. $8^{\text {th }}$ edition, Delhi: Peason Education (Singapore) Pte Ltd. Indiana Branch.

[24]. Uniamikogbo, S. O. (1996). Nigeria's Non-Oil Export Sector: An Analysis of Some Issues for consideration beyond adjustment. The Nigeria Journal of Economic and Social Studies. 38(2), pp. 129-151. 